\title{
Decadal trend in lobster reproductive output from a temperate marine protected area
}

\author{
David Díaz ${ }^{1, *}$, Sandra Mallol ${ }^{1}$, Ana M. Parma ${ }^{2}$, Raquel Goñi ${ }^{1}$ \\ ${ }^{1}$ Centro Oceanográfico de Baleares, IEO, Muelle de Poniente s/n 07015 Palma de Mallorca, Spain \\ ${ }^{2}$ Centro Nacional Patagónico, Boulevard Brown 2915 U 9120 ACF Puerto Madryn, Chubut, Argentina
}

\begin{abstract}
Increased recruitment from eggs and larvae exported from marine protected areas (MPAs) is anticipated to produce much greater benefits for exploited populations than spillover of adults. However, resolving the link between local egg production and regional recruitment is beyond current research capabilities, and quantifying the contribution of the MPA to regional reproductive output is the first step towards evaluating such potential. In this study, we assessed the egg production of spiny lobsters Palinurus elephas in the Columbretes MPA (western Mediterranean, Spain) and its contribution to regional reproductive output over the decade corresponding to years 10 to 19 of protection. We show that: (1) Mean female fecundity in the MPA increased by $41 \%$ over the $10 \mathrm{yr}$ of study and in recent years was more than twice the fecundity in the nearby fished areas. (2) At the end of the study, mature females were on average 20 times more abundant, and egg production per unit area was 30 times greater in the MPA than in nearby fished areas. (3) At that time, the MPA, occupying $18 \%$ of the regional lobster habitats, was responsible for over $80 \%$ of the regional egg production. Overall, we estimate that after nearly 2 decades of protection, regional egg production was 6 times greater than would have been without the MPA. When compared to a net benefit through biomass spillover from the MPA to the regional lobster fishery of $+11 \%$ of the annual catch, a 6 -fold increase in egg production suggests that egg and larval export have far greater potential than spillover to benefit exploited populations.
\end{abstract}

KEY WORDS: Marine reserve - Mean fecundity - Reproductive contribution - Spiny lobster · Palinurus elephas

Resale or republication not permitted without written consent of the publisher

\section{INTRODUCTION}

Marine protected areas (MPAs) that effectively rebuild biomass of exploited species within their boundaries are expected to benefit local fisheries through biomass spillover and export of eggs and larvae (Hilborn et al. 2004). Biomass spillover of adults has now been quantified (e.g. Goñi et al. 2010) or demonstrated from tag-recapture experiments (e.g. Tupper 2007, Goñi et al. 2010) and inferred from spatial or temporal patterns of catch and effort (see review by Goñi et al. 2011). Observable adult spillover effects documented so far, even if significant, are limited to a few hundred or thousand metres from MPA boundaries (Goñi et al. 2006, 2008, Halpern et al. 2010). In contrast, egg and larvae export and their effects on recruitment are anticipated to produce much greater benefits for fisheries than spillover (e.g. Jennings 2001, Russ 2002, Moffitt et al. 2009). However, the potential effect of exported larvae on recruitment enhancement is hard to assess due to the high spatial and temporal variability of larval survival and settlement, as well as the large area over which larvae may disperse (e.g. Botsford et al. 2009). This has hampered research, and few empirical studies have addressed the recruitment effects of MPAs. At present, and despite their intuitiveness, empirical evidence of such MPA recruitment effects on exploited populations remains elusive, and most research is currently focused on unravelling larval dispersal and population connectivity patterns through genetic paternity studies (e.g. Jones et al. 2009, Planes et al. 2009).

The potential of MPAs as seeding areas of exploited species demands evaluation, despite the difficulties of 
resolving the link between local egg production and regional recruitment. Differences in reproductive output of populations within and outside MPAs have been assessed in fishes (Denny et al. 2004, Evans et al. 2008) and molluscs (Manríquez \& Castilla 2001), but lobsters have received the most attention. In particular, Babcock et al. (2007) found that after $17 \mathrm{yr}$ without fishing, egg production of Panulirus cygnus per unit area in a small Western Australian MPA was 100-fold higher than in fished areas. In most cases, however, reported differences have been much less pronounced. For example, egg production of Jasus edwardsii was estimated to be 8 times higher in a New Zealand MPA $15 \mathrm{yr}$ after fishing ceased than in exploited areas, and only 3 times higher in a newer 3 yr old MPA (Jack \& Wing 2010). That greater egg production in MPAs relies on recovery of numbers and size of protected individuals was shown in a study of 3 South African MPAs that were ineffective at rebuilding lobster J. lalandii biomass (Mayfield et al. 2005). Most studies have been based on one-time spatial comparisons of unfished and fished areas, and temporal effects have at best been inferred indirectly by comparing MPAs of different age. Kelly et al. (2000) estimated a $6 \%$ annual increase of lobster $J$. edwardsii egg production by combining studies from 3 New Zealand MPAs. Trends over time in a single location have not been evaluated and therefore the time dynamics of reproduction and recruitment potential are unclear.

In the Columbretes Islands MPA, the effects of the cessation of fishing on egg production of the European spiny lobster Palinurus elephas were studied 8 to $10 \mathrm{yr}$ after its establishment (Goñi et al. 2003a). A spatial comparison indicated that egg production per unit area was 5 to 20 times greater in the MPA than in fished areas depending on the season. Monitoring was continued until $19 \mathrm{yr}$ after the MPA creation, thus providing the first decade-long time series of egg production change in an MPA. This paper assesses the egg production of $P$. elephas in the MPA and its contribution to regional reproductive output between the 10th to 19th years of protection. Our goals were to estimate female fecundity and egg production in the MPA and adjacent fished areas over time to determine the fraction of regional egg production contributed by the MPA. To evaluate this, we used female lobster size, published size-fecundity relationship (Goñi et al. 2003a), and catch per unit effort (CPUE) information from fishing surveys conducted in and outside the MPA.

\section{MATERIALS AND METHODS}

Species. Palinurus elephas is a deep-water, temperate spiny lobster species widely distributed in the
Northeast Atlantic and the Mediterranean. It inhabits rocky and coralligenous habitats from near shore to depths of $200 \mathrm{~m}$; in the study area, this species reaches maximum densities at depths of 60 to $90 \mathrm{~m}$, and adults are rare above $40 \mathrm{~m}$ depth (Goñi et al. 2003b). P. elephas is a long-lived (maximum estimated age 20+ yr; Díaz 2010), slow-growing species that reproduces once a year (Goñi \& Latrouite 2005). In the Mediterranean, $P$. elephas matures at age 3 to $4 \mathrm{yr}$ ( $\sim 80 \mathrm{~mm}$ carapace length, CL), the egg-bearing period extends from September to February (Goñi et al. 2003a), and moulting of males (females) peaks in winter (spring) (Goñi \& Latrouite 2005). Tagging studies conducted in the Atlantic and Mediterranean indicate that adult movement is restricted, with most individuals moving $<5 \mathrm{~km}$, although there are occasional reports of recaptures up to $70 \mathrm{~km}$ away (Goñi \& Latrouite 2005). Inshore-offshore migrations linked to reproduction and feeding have been reported for both Atlantic and Mediterranean populations, and have been inferred for the MPA population on the basis of seasonal bathymetric changes in size and sex structure (Goñi et al. 2001).

Study site and fishery. The study was carried out in the Columbretes Islands MPA (western Mediterranean, Spain) and surrounding fishing grounds. Situated $50 \mathrm{~km}$ from the coast at the edge of the continental shelf, the MPA protects $44 \mathrm{~km}^{2}$ (expanded to $55 \mathrm{~km}^{2}$ in 2009) of volcanic rock and coralligenous habitats (maërl beds), with patches of gravel, sand or mud extending down to $80 \mathrm{~m}$ depth. The regional fishing grounds near the MPA consist of patches of rock or maërl over expanses of gravel, sand and mud primarily at depths of 50 to $100 \mathrm{~m}$ and extending up to $30 \mathrm{~km}$ from the MPA limits. No lobster fishing occurs beyond those grounds, which are surrounded by sandy substrates where bottom trawl groundfish fisheries operate. The MPA harbours traditional fishing grounds of Palinurus elephas; legislation prohibits all commercial fisheries and all lobster fishing, and these regulations are well enforced.

Commercially, Palinurus elephas is the most important spiny lobster in the Mediterranean and Northeastern Atlantic. In most western Mediterranean fisheries, lobsters are caught with trammel nets set over rocky and coralligenous habitats. Trammel nets are groups of 3 rectangular nets made up of 2 outer, large-mesh panels and 1 inner, smaller-mesh panel (see Goñi et al. 2003b for further details). Northwestern Mediterranean fisheries are managed by a closed season during the egg-bearing period (September to February), a minimum landing size of $90 \mathrm{~mm} C L$ and the prohibition of landing berried females.

Although Mediterranean populations are highly depleted and considered overfished, they are still tar- 
geted by small artisanal boats in many areas, especially around archipelagos and islands (Goñi \& Latrouite 2005). The MPA was established in an offshore location, exploited by only a few boats large enough to venture that far and, after the MPA creation, the number of boats further declined. During the study period, 3 to 4 boats fished consistently through the season from 2000 to 2003, and only 2 boats operated in later years; however, increased effort per boat in recent years has maintained regional effort (Goñi et al. 2010).

Spatially, lobster fishing is distributed near the MPA ( $<1 \mathrm{~km}$ from the boundary: border zone), in adjacent grounds up to $5 \mathrm{~km}$ from the MPA (1 to $5 \mathrm{~km}$ from the boundary: adjacent zone) and in patchily distributed grounds farther away (5 to $30 \mathrm{~km}$ from the boundary: far zone; Fig. 1).

Data collection. Data on catch, effort and female size (CL measured from the tip of the rostral spine to the posterior edge of the carapace, in $\mathrm{mm}$ ), were obtained from experimental and commercial fishing operations as follows:

MPA: Experimental fishing surveys inside the MPA were conducted annually since 1997, 7 yr after MPA creation. Although the timing of the survey and gear used were varied initially, standardised data all collected in June with trammel nets are available from 2000 to 2009 , totalling 217 fishing sets $(n=102$ at $\leq 50 \mathrm{~m}$ and 115 at $>50 \mathrm{~m}$ ). The surveys were conducted by a chartered commercial boat and crew who fished with trammel nets identical to those used in commercial operations described below and following a random sampling design over rocky and coralligenous habitats where lobsters are known to occur, and from 25 to $80 \mathrm{~m}$ depth (maximum depth in the MPA). See Goñi et al. (2003b) for a detailed description of the survey methods.

Adjacent fishing grounds: Data from the commercial fishery were recorded from 2000 to 2009 during the 6 mo (March to August) annual lobster fishing season. Whenever possible, sampling took place during $1 \mathrm{wk}$ $\mathrm{mo}^{-1}$ on board one of the boats that consistently fished in the region. The observer sampled all fishing sets that were carried out in that week, recording data on net length, location, depth and lobster catch. Over the study period, 684 fishing sets (border $=266$, adjacent $=$ 187, $\mathrm{far}=231$ ) were recorded within $30 \mathrm{~km}$ of the MPA boundary (Fig. 1).

Data analysis. Mean female fecundity: Average female fecundity $\left(F F\right.$, no. eggs female $\left.{ }^{-1}\right)$ was estimated from the size composition of female lobsters in the catch using the size-fecundity (F) relationship obtained for Palinurus elephas in the MPA: F $=2428 \times \mathrm{CL}$ (mm) - 148988, and assuming a knife-edge maturity schedule with size at maturity of $78 \mathrm{~mm}$ CL (Goñi et al.
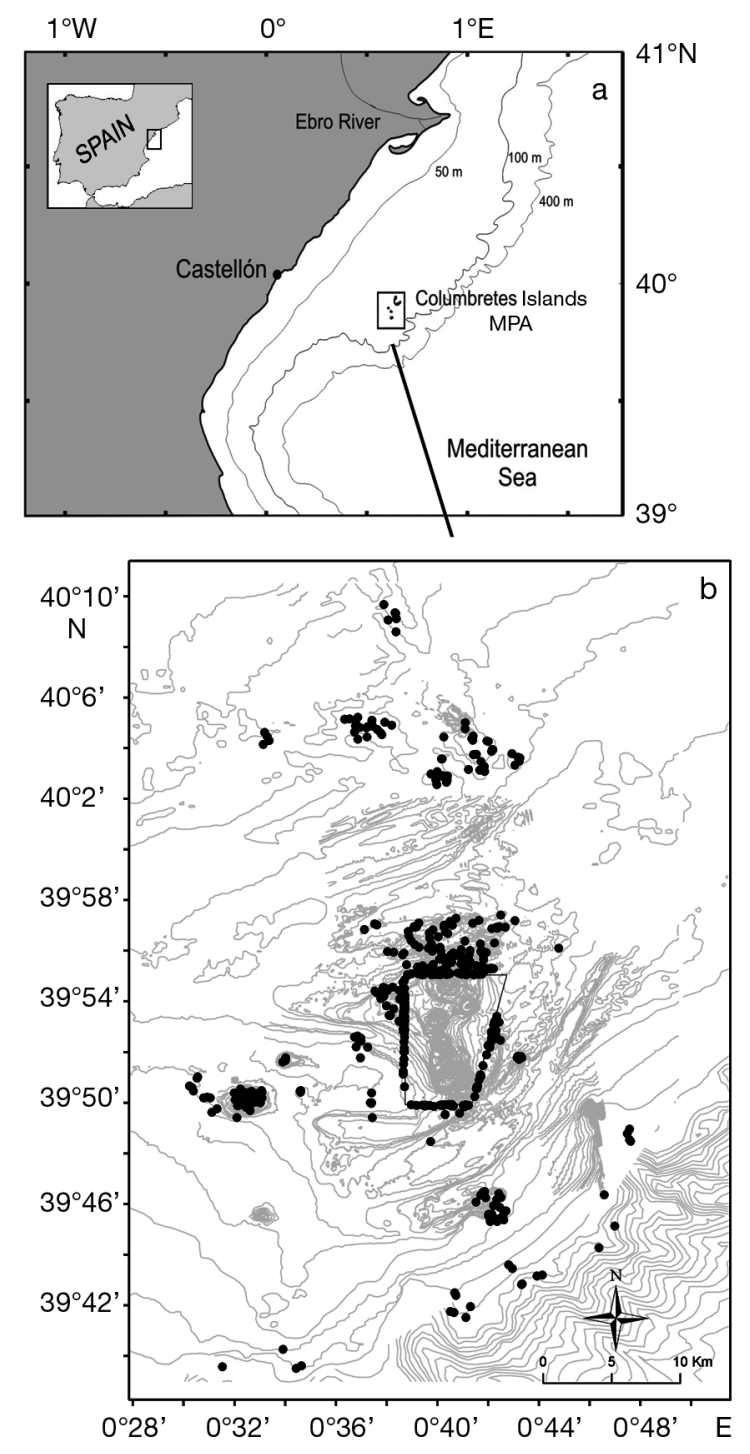

Fig. 1. Columbretes Islands marine protected area (MPA) on the continental shelf of the Iberian Peninsula (a) and bathymetric map of the region (b). Dots are commercial fishing sets sampled and illustrate the spatial distribution of lobster fishing effort in the region

2003a). Linear regression models and a power curve were fitted to average FF as a function of time (yr 2000 to 2009) to estimate trends in 2 strata within the MPA: shallow $(\leq 50 \mathrm{~m})$ and deep $(>50 \mathrm{~m})$, and in the fished area outside the MPA ('outside'). The significance of non-linear trends (i.e. power coefficient different than 1) was assessed by comparing the linear and power models using likelihood ratio tests. FF in the MPA and in fished areas at increasing distances from it (border, adjacent and far) were estimated for the most recent 3 yr period (2007 to 2009) and compared by 1way analysis of variance (ANOVA). A Tukey multiple 
comparison test was used after ANOVA to investigate differences between means.

Egg production per unit area: The study area was divided in $1 \times 1 \mathrm{~km}$ spatial cells, and fishing sets were assigned to the corresponding cells. Female CPUE was calculated for each cell as the total number of female lobsters caught divided by the total number of nets (net length $=50 \mathrm{~m}$ ) deployed in that cell. Egg production (number of eggs) per unit area (EPUA) was estimated from the cell mean FF multiplied by the cell CPUE. Average EPUA for the 2 depth strata (shallow: $\leq 50 \mathrm{~m}$; deep: $>50 \mathrm{~m}$ ) was calculated as a simple average over sampled cells. The SE of the average EPUA was estimated by bootstrap in 2 steps to mimic the 2-stage sampling method used in the surveys: (1) cells were resampled with replacement and (2) females caught within each resampled cell were resampled to calculate the cell EPUA. The SD of the average EPUAs for each stratum was calculated after repeating the 2stage resampling 1000 times.

Annual trends in average EPUA between 2000 and 2009 in the shallow and deep strata of the MPA and in the fishing grounds outside the MPA were estimated using linear regression and a power curve. Models were compared using likelihood ratio tests. Average EPUA in the MPA and in fished areas at increasing distances from it (border, adjacent and far) were estimated for the most recent 3 yr period (2007 to 2009) and compared by 1-way ANOVA. A Tukey multiple comparison test was used after ANOVA to investigate differences between means.

MPA contribution to regional egg production: To assess the MPA contribution to regional egg production $\left(E P U A_{\mathrm{MPA}}\right)$ over time, we first calculated the EPUA for the whole region $\left(E P U A_{\text {tot }}\right)$ as:

$$
E P U A_{\text {tot }}=\sum_{i} E P U A_{i} \times A_{i}
$$

where $E P U A_{i}$ is the average EPUA for zone $i$ ( $i=$ MPA, border, adjacent, far), and $A_{i}$ is the fraction of regional lobster habitat in zone $i$. The extension of the regional lobster grounds outside the MPA was calculated as the sum of all $1 \times 1 \mathrm{~km}$ cells where at least 1 fishing set was registered since the start of the study in 1997. Within the MPA, all $1 \times 1 \mathrm{~km}$ cells encompassing lobster habitats (i.e. excluding sand and mud substrate) were counted as lobster grounds. The regional lobster grounds cover $189 \mathrm{~km}^{2}$, of which the MPA occupies $34 \mathrm{~km}^{2}$.

The fraction of regional egg production coming from the MPA was calculated as:

$$
\% M P A=E P U A_{\mathrm{MPA}} \times A_{\mathrm{MPA}} / E P U A_{\text {tot }}
$$

MPA difference in system-wide egg production: We estimated the difference in egg production attributable to the MPA by comparing the regional egg production
$E P U A_{\text {tot }}$ with and without MPA in recent years (2007 to 2009). To do this, we assumed that the mean EPUA of the system without the MPA would have been the same as the mean EPUA estimated for the fished area $\left(E P U A_{\text {out }}\right)$. We then calculated relEPUA $A_{i}$ defined as the $E P U A_{i}$ for each zone $i$ relative to that baseline $E P U A_{\text {out }}$ as:

$$
\text { relEPUA } A_{i}=E P U A_{i} / E P U A_{\text {out }}
$$

The net effect of the MPA on egg production was the sum of the relative $E P U A_{i}$ in the 4 zones ( $i=\mathrm{MPA}$, border, adjacent, far) multiplied by the fraction of the regional lobster habitat in each zone $\left(A_{i}\right)$ :

$$
\Delta r e l E P U A=\sum_{i} \operatorname{relEPUA} A_{i} \times A_{i}
$$

\section{RESULTS}

\section{Mean female fecundity (FF)}

Mean FF in the MPA increased by $41 \%$ over the first $8 \mathrm{yr}$ of the study period, from a mean value of 92300 eggs female ${ }^{-1}$ in 2000, and remained stable during the latter 3 yr $(F=0.04$; p > 0.99; Tukey's multiple comparison tests $\mathrm{p}>0.96$; Fig. 2). Despite this recent stabilisation, the linear model was selected in favour of the power curve (likelihood ratio test $=0.65$, df $=1, \mathrm{p}=$ 0.42). Mean FF was greater in shallow than in deep waters within the MPA (Fig. $2 ; t=5.06, \mathrm{p}<0.000$ ), but the trends over time were not significantly different $(t=1.76, \mathrm{p}=0.098)$. This bathymetric difference reflected the greater proportion of large females in shallow than in deep areas of the MPA (Fig. 3a,b).

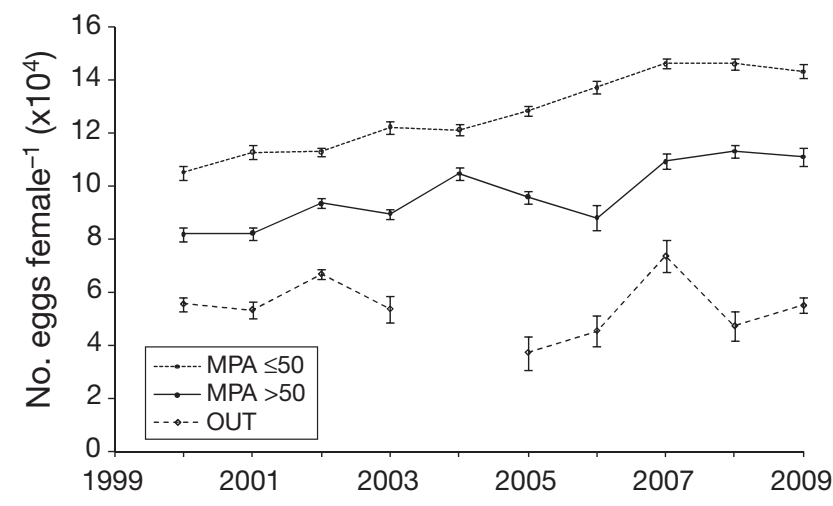

Fig. 2. Palinurus elephas. Trend of female fecundity (FF, number of eggs) in the shallow (MPA $\leq 50 \mathrm{~m}$ ) and deep (MPA $>50 \mathrm{~m}$ ) strata within the marine protected area (MPA) and in the fished area outside (OUT). Means $\pm 1 \mathrm{SE}$ 
In the fished area, mean FF oscillated episodically (Fig. 2, Table 1). In the latter years, mean FF in the MPA was 2.3 times greater than in the fished areas. Although FF was not significantly different among the 3 fished zones $(F=1.97, \mathrm{p}=0.14$; Tukey's multiple com-
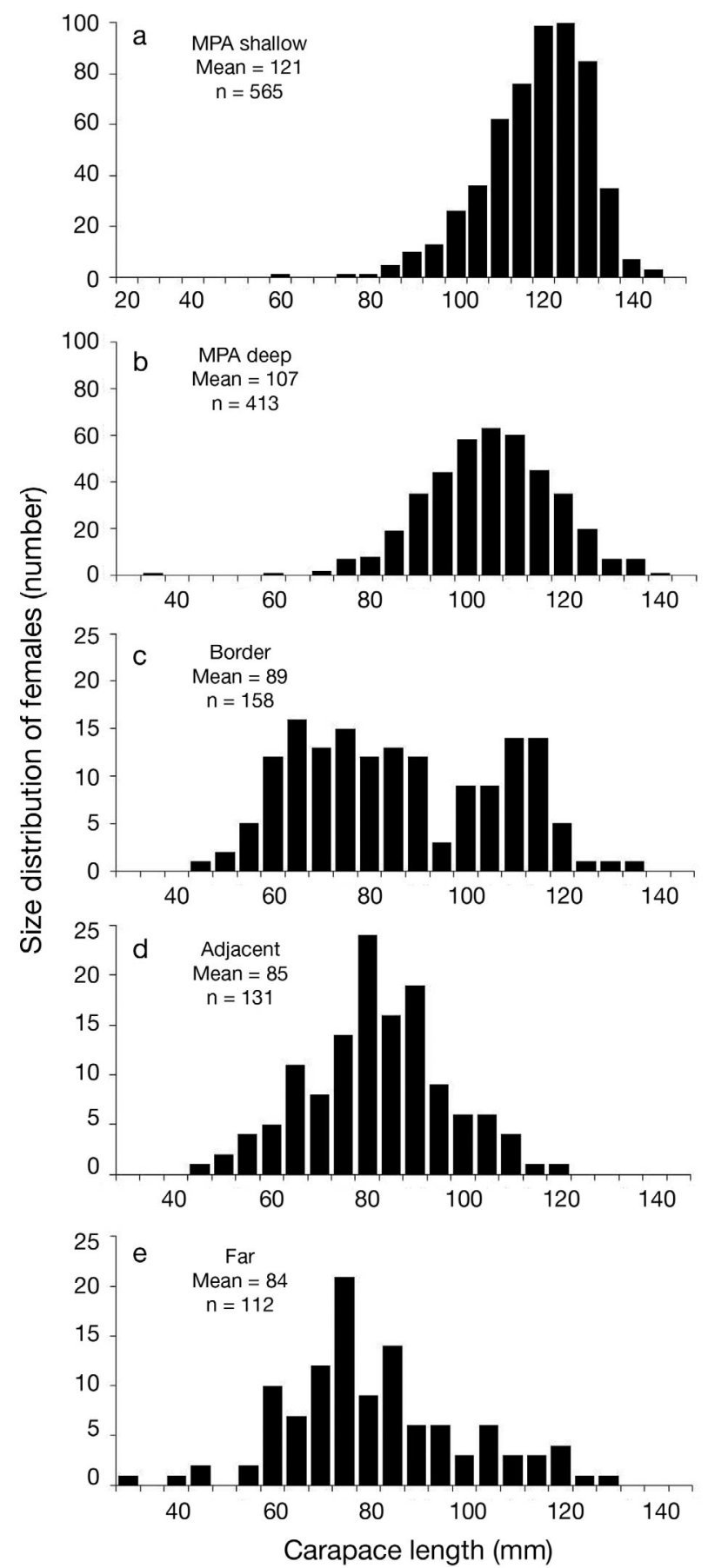

Fig. 3. Palinurus elephas. Size distribution of females (number) in (a) marine protected area (MPA) shallow ( $\leq 50 \mathrm{~m})$ and (b) MPA deep (>50 m) strata and (c) in fished areas outside within $1 \mathrm{~km}$ of the MPA (Border), (d) at 1 to $5 \mathrm{~km}$ (Adjacent) and (e) at $>5 \mathrm{~km}$ (Far). Data of 2007 to 2009 combined parison tests $\mathrm{p}>0.05), \mathrm{FF}$ in the border area $(<1 \mathrm{~km}$ from the MPA) was on average higher than in farther fishing grounds (Table 2), in correspondence with the greater proportion of large females in that zone (Fig. 3c-e).

\section{Egg production per unit area (EPUA)}

In the MPA, mean EPUA oscillated episodically (Fig. 4). The linear model was selected over the power curve (likelihood ratio test $=0.44$; $\mathrm{df}=1 ; \mathrm{p}=0.51$ ), but the slope was not significantly different than 0 (Table 1). Oscillations of EPUA in the MPA were dominated by variations of mature female CPUE (not shown), which declined slightly, primarily in deep waters (Table 1). This did not translate into a significant decline of EPUA in the overall MPA ( $p=0.123$ ) due to the concomitant increase of mean female size, and therefore fecundity, particularly in shallow waters (Table 1).

In the fished area, EPUA remained stable over the study period, as did mature female CPUE (Table 1), which was on average 14 times lower than in the MPA (not shown). In recent years, mean EPUA in the MPA (Table 2) was about 30 times greater than in the fished grounds $\left(E P U A_{\text {out }}=6.8 \times 10^{3}\right.$ eggs $)$. During 2007 to 2009, EPUA was on average $30 \%$ higher in the border zone and $20 \%$ lower in the distant zone than the EPUA for the overall fished area EPUA ${ }_{\text {out }}$ (Table 2).

\section{MPA contribution to regional egg production}

The fraction of regional egg production originating in the MPA increased from 0.73 to 0.87 over the study period (Fig. 5). After 17 to $19 \mathrm{yr}$ of protection, regional

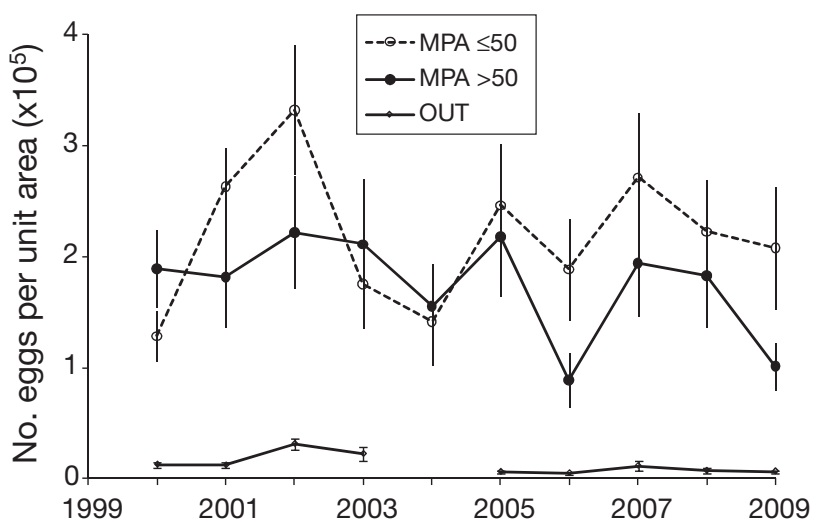

Fig. 4. Palinurus elephas. Trend of egg production per unit area (EPUA, number of eggs) in the shallow (MPA $\leq 50 \mathrm{~m}$ ) and deep (MPA $>50 \mathrm{~m}$ ) strata within the marine protected area (MPA) and in the fished area outside (OUT). Means $\pm 1 \mathrm{SE}$ 
Table 1. Palinurus elephas. Linear regressions of female fecundity (FF), egg production per unit area (EPUA) and catch per unit effort (CPUE: number of lobsters net $\left.{ }^{-1}\right)$ as a function of time in the shallow $(\leq 50 \mathrm{~m})$ and deep (>50 m) strata within the marine protected area (MPA), and in the fished area outside (OUT). SE of the parameter estimates in parentheses. Significant values $(p<0.05)$ in bold

\begin{tabular}{|lccrr|}
\hline & Intercept & Slope & \multicolumn{1}{c|}{$t$} & $\mathrm{p}$ \\
\hline FF & & & & \\
MPA $\leq 50 \mathrm{~m}$ & $105887(2290)$ & $4821(429)$ & 11.240 & $<\mathbf{0 . 0 0 1}$ \\
MPA $>50 \mathrm{~m}$ & $82013(3986)$ & $3306(747)$ & 4.428 & $\mathbf{0 . 0 0 2}$ \\
OUT & $55656(7060)$ & $-339(1291)$ & -0.263 & 0.800 \\
EPUA & & & & \\
MPA $\leq 50 \mathrm{~m}$ & $210227(38941)$ & $1669(7294)$ & 0.229 & 0.825 \\
MPA $>50 \mathrm{~m}$ & $207822(25129)$ & $-7424(4707)$ & -1.577 & 0.153 \\
OUT & $19624(4694)$ & $-1502(859)$ & -1.749 & 0.124 \\
CPUE & & & & \\
MPA $\leq 50 \mathrm{~m}$ & $1.89(0.32)$ & $-0.04(0.06)$ & -0.692 & 0.508 \\
MPA $>50 \mathrm{~m}$ & $2.29(0.24)$ & $-0.12(0.05)$ & -2.606 & $\mathbf{0 . 0 3 1}$ \\
OUT & $0.22(0.04)$ & $-0.02(0.01)$ & -2.190 & 0.065 \\
& & & & \\
\hline
\end{tabular}

egg production in the system with the MPA was estimated to be 6 times greater than without the MPA at the latter levels of lobster depletion (Table 2).

\section{DISCUSSION}

An expected benefit of protecting overexploited populations is the enhancement of reproduction and subsequent increases in egg and larval export (Jennings 2001, Russ 2002, Moffitt et al. 2009). This study indicates that mean fecundity of Palinurus elephas in the Columbretes Islands MPA increased substantially over time, and after 2 decades of fisheries closure, MPA fecundity accounted for $80 \%$ of the regional egg production despite occupying only $18 \%$ of lobster habitats. As a result, the system with the MPA produced $600 \%$ more eggs than without an MPA. During the $10 \mathrm{yr}$ of study, this benefit was maintained by the growing size of mature females in the protected population rather than by their abundance, which did not increase.

Growth in size translates linearly into increased egg production due to the linear relationship between fecundity and female CL observed in Palinurus elephas (De Vasconcellos 1960, Goñi et al. 2003b, Galhardo et al. 2006), similarly to other Palinurus species (e.g. P. gilchristi, Groeneveld 2005). This is in contrast to spiny lobsters of the genera Panulirus and Jasus, where fecundity has been shown to increase exponentially with size (e.g. P. marginatus: DeMartini et al. 2003; P. penicillatus: Chang et al. 2007; P. cygnus: Babcock et al. 2007; P. regius: Freitas et al. 2007; J. edwardsii: Smith \& Ritar 2007, Green et al. 2009, Linnane et al. 2009). Because of the linearity of the fecundity-size relationship, in $P$. elephas benefits of protection for egg production will not increase exponentially with time as would in other spiny lobsters, and egg production per unit biomass will decline in larger females (Goñi et al. 2003a).

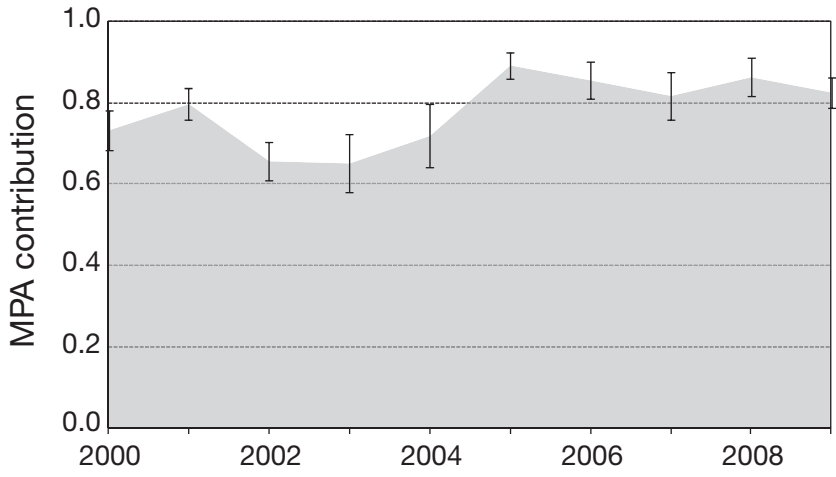

Fig. 5. Palinurus elephas. Fraction of regional egg production contributed by the marine protected area (MPA; grey) over time. Vertical lines represent \pm 1 SE

Table 2. Palinurus elephas. Reproductive contribution of the marine protected area (MPA). Statistics for each zone $i$ are: mean female fecundity $\left(\mathrm{FF}_{i}\right.$ in thousands), egg production per unit area $\left(E P U A_{i}\right.$ in thousands), fraction of regional lobster habitat $\left(A_{i}\right)$, mean $E P U A_{i}$ relative to mean EPUA in the fished area (Relative EPUA), contribution to regional egg production (Relative EPUA ${ }_{i} \times$ $A_{i}$ ) and relative EPUA weighed by the fraction of lobster habitat in each zone (\% of total egg production). Zones: MPA, Border (fished area within $1 \mathrm{~km}$ of the MPA), Adjacent (fished area within 1 to $5 \mathrm{~km}$ of the MPA) and Far (fished area within $>5 \mathrm{~km}$ of the MPA). Data are means (SE) of the period 2007 to 2009

\begin{tabular}{|c|c|c|c|c|c|c|}
\hline Zone & $\mathrm{FF}_{i}$ & $E P U A_{i}$ & $\begin{array}{l}\text { Fraction of } \\
\text { habitat }\left(A_{i}\right)\end{array}$ & $\begin{array}{l}\text { Relative EPUA } \\
\left(E P U A_{i}: E P U A_{\text {out }}\right)\end{array}$ & $\begin{array}{c}\text { Relative } \\
E P U A_{i} \times A_{i}\end{array}$ & $\begin{array}{c}\% \text { of total } \\
\text { egg production }\end{array}$ \\
\hline MPA & $130.9(1.1)$ & $202.6(20.9)$ & 0.18 & 29.66 & 5.34 & 87 \\
\hline Border & $61.9(4.3)$ & $9.0(2.4)$ & 0.12 & 1.32 & 0.16 & 3 \\
\hline Adjacent & $54.5(3.4)$ & $7.1(1.5)$ & 0.27 & 1.04 & 0.28 & 5 \\
\hline Far & $50.5(4.6)$ & $5.5(1.5)$ & 0.43 & 0.80 & 0.35 & 5 \\
\hline Total & - & - & 1 & - & 6.12 & 100 \\
\hline
\end{tabular}


Mean FF in the MPA increased by $41 \%$ during the $10 \mathrm{yr}$ of study and in recent years was more than twice the average FF in the fished area. A similar difference in mean fecundity between unfished and fished populations was found for Panulirus argus in the Dry Tortugas National Park (Florida, USA) after 20 yr of protection (Bertelsen \& Matthews 2001). Interestingly, in both cases these effects were evaluated after protection periods close to the maximum life span of these species when the cohorts present had not been affected by fishing.

Although we could not reject an overall linear increase over the whole study period, mean FF in the MPA has been stable over the last $3 \mathrm{yr}$, suggesting that size and therefore potential fecundity may be approaching an asymptote. Tag-recapture data of Palinurus elephas in the MPA indicate a marked reduction in female growth well before they reach their potential maximum size $\left(\mathrm{L}_{\max }=145 \mathrm{~mm}\right.$ CL; Díaz 2010). P. elephas is a slow-growing species with an estimated maximum age of 20+ yr (Díaz 2010). Hence, after 19 yr without fishing, the largest lobsters in the MPA should be close to $L_{\max }$ and a limit to the contribution of female size to egg production may have been reached. Further egg production increases would depend on recruitment of young females to the brood stock.

FF in the fished area remained stable over the decade of study. Outside the MPA, female size oscillated around a mean of $84 \mathrm{~mm} \mathrm{CL}$, slightly above the size at maturity (Goñi et al. 2003b) and below the minimum landing size of $90 \mathrm{~mm}$ CL. Dramatic reductions of spawning potential in exploited areas associated with severely reduced abundance of large females have been also documented for Panulirus argus (Lyons et al. 1981) and Jasus edwardsii (Kelly et al. 2000). High exploitation rates characterise many spiny lobster fisheries, where few lobster in the legal size classes escape the fishery every year (e.g. Rowe 2001, Iacchei et al. 2005). Notably, mean FF near the MPA, slightly higher than in farther fishing grounds, reveals the process of spillover documented for Palinurus elephas whereby migrants exiting the MPA and caught in the adjacent fishery were about 30\% larger than local lobsters (Goñi et al. 2010).

Our study did not account for possible changes in size-specific fecundity over time and improved egg quality produced by older females. As a result, we may be underestimating the positive impact on effective reproduction associated with demographic recovery within the MPA. FF at size was estimated based on samples collected in the MPA $10 \mathrm{yr}$ ago (Goñi et al. 2003a). This relationship may underestimate present fecundity in the MPA if the increased abundance of large males within the MPA (R. Goñi et al. unpubl. data) had a positive effect on effective fecundity, as has been shown in other spiny lobsters (MacDiarmid \& Butler 1999). A second reason we may be undervaluing the reproductive benefits derived from protection is that in Palinurus elephas mean egg diameter increases with female size (Goñi et al. 2003b), and if large eggs hatch more competent larvae (Smith \& Ritar 2007, A. MacDiarmid unpubl. data), the positive effects of increased egg production associated with demographic recovery would be amplified. On the other hand, a minor underestimation of mean fecundity in the fished area may result from the fact that a small fraction of the females collected outside were sampled before the peak spring moult.

At the end of the study, mature females were on average 20 times more abundant and EPUA was 30 times greater in the MPA than in the fished grounds. However, EPUA in the MPA did not grow despite the sustained increase in FF because the abundance of mature females declined. Goñi et al. (2010) attributed this decline of lobster abundance largely to 'dispersal imbalance' (sensu Walters et al. 2007), i.e. emigration from the MPA that is not compensated by immigration due to the high exploitation rates in the adjacent fishery. In particular, an extraordinary storm caused a massive emigration of lobsters in the winter of 2001 and a marked decline of abundance in the MPA (Goñi et al. 2010).

In our earlier study of the same population (1998-2000; Goñi et al. 2003a), greater egg production in the MPA was attributed primarily to higher female abundance (similar to present levels). At that time, when the MPA had only been closed to fishing for $10 \mathrm{yr}$ (about half the maximum life span of the species), females were only slightly (4\%) larger on average than those of nearby exploited populations, and had not realised their maximum lifetime reproductive potential. Now, after 10 more years without fishing, abundance has stabilised and the effect of cumulative growth is taking over. A $30 \%$ greater female size and 14 times greater mature female abundance are maintaining high levels of egg production relative to local fishing grounds. We conclude that for slow-growing species, the initial effects of protection on egg production will be mainly derived from the reduced mortality of adults, which will be gradually followed by the effects of growth on fecundity.

Overall, we estimate that after 2 decades of protection, regional egg production was over 6 times greater than would have been without the MPA. This conclusion rests on the assumption that, had the MPA not been established, EPUA in those grounds would have been similar to the EPUA that we estimated for the fished area. This in turn assumes that the displaced fishing effort has not resulted in increased exploitation rates in the grounds remaining open. 
Although increased exploitation through effort displacement would be a reasonable expectation, in the particular case of Columbretes the creation of the MPA initially led to a reduction in fishing effort because it discouraged fishers coming from the most distant harbours (i.e. the Balearic Islands, $>12 \mathrm{~h}$ sailing time). Since the beginning of monitoring in 1997, regional lobster effort has remained roughly stable (Goñi et al. 2010).

When compared to the net benefit of biomass spillover from the Columbretes MPA to the regional lobster fishery of $+11 \%$ of the annual catch (Goñi et al. 2010), a 6 times greater egg production supports the contention that egg and larval export have far greater potential than spillover to benefit exploited populations. In practice this will be very difficult to determine, in particular in the case of MPAs that are small relative to the potential extent of larval dispersal. The size $\left(44 \mathrm{~km}^{2}\right)$ of the Columbretes MPA is well above average (Francour et al. 2001), but likely small relative to the dispersal potential of Palinurus elephas with a pelagic phase of 4 to 5 mo (Goñi \& Latrouite 2005). Genetic studies indicate that $P$. elephas in the Western Mediterranean are interconnected (Babbucci et al. 2010), and regional populations may be linked via a common larval pool among intermediate populations (Díaz 2010). Nevertheless, although recruitment of locally spawned larvae to the MPA appears unlikely, a growing body of evidence of fish larval dispersal patterns indicates that larval retention in, or return to, parental grounds is far more important than previously believed (Jones et al. 2009).

While at present uncertainty about larval connectivity and dispersal bars further assessment of the actual impact of reproductive output from MPAs, the dominant contribution of the Columbretes MPA to the regional lobster reproduction is remarkable. In cases such as the European spiny lobster fisheries, where other means to regulate fishing pressure are largely ineffective due to poor enforcement capability, a network of interconnected MPAs seeding the exploited fishing grounds may prove to be the only way to maintain a viable metapopulation and fishery.

Acknowledgements. We thank the skippers and crews of the 'Calypso' and 'Catalá' for their invaluable collaboration, and O. Reñones and A. Quetglas for their contribution to the design of the study and data collection in the early years of the project. We acknowledge the helpful comments of the editor and 2 anonymous reviewers, which significantly improved this paper. This work was supported by the Spanish Secretaría General del Mar by grants to the Instituto Español de Oceanografía (IEO) for the LANGOSTA and ERICOL projects. The manuscript was prepared while A.M.P. was a visiting scientist at the IEO Centro Oceanográfico de Baleares with support provided by the Secretaría General de Universidades del Ministerio de Educación de España.

\section{LITERATURE CITED}

Babbucci M, Buccoli S, Cau A, Cannas R and others (2010) Population structure, demographic history, and selective processes: contrasting evidences from mitochondrial and nuclear markers in the European spiny lobster Palinurus elephas (Fabricius, 1787). Mol Phylogenet Evol 56: 1040-1050

Babcock RC, Phillips JC, Lourey AM, Clapin G (2007) Increased density, biomass and egg production in an unfished population of western rock lobster (Panulirus cygnus) at Rottnest Island, Western Australia. Mar Freshw Res 58:286-292

> Bertelsen RD, Matthews TR (2001) Fecundity dynamics of female spiny lobster (Panulirus argus) in a south Florida fishery and Dry Tortugas National Park lobster sanctuary. Mar Freshw Res 52:1559-1565

Botsford LW, White JW, Coffroth MA, Paris CB and others (2009) Connectivity and resilience of coral reef metapopulations in marine protected areas: matching empirical efforts to predictive needs. Coral Reefs 28:327-337

Chang YJ, Sun CL, Chen Y, Yeh SZ, Chiang WC (2007) Reproductive biology of the spiny lobster, Panulirus penicillatus, in the southeastern coastal waters off Taiwan. Mar Biol 151:553-564

DeMartini EE, DiNardo GT, Williams HA (2003) Temporal changes in population density, fecundity, and egg size of the Hawaiian spiny lobster (Panulirus marginatus) at Necker Bank, northwestern Hawaiian Islands. Fish Bull 101:22-31

> Denny CM, Willis TJ, Babcock RC (2004) Rapid recolonisation of snapper Pagrus auratus: Sparidae within an offshore island marine reserve after implementation of no-take status. Mar Ecol Prog Ser 272:183-190

De Vasconcellos GM (1960) On the size relation and fecundity of the stock of spiny lobster, Palinurus vulgaris Lat., at the coast of Portugal. ICES CM Shellfish Committee 219:1-6

Díaz D (2010) Ecology of juveniles of European spiny lobster Palinurus elephas in the north-western Mediterranean. $\mathrm{PhD}$ dissertation, University of Barcelona (in Spanish)

> Evans RD, Russ GR, Kritzer JP (2008) Batch fecundity of Lutjanus carponotatus (Lutjanidae) and implications of notake marine reserves on the Great Barrier Reef, Australia. Coral Reefs 27:179-189

> Francour P, Harmelin JG, Pollard D, Sartoreto S (2001) A review of marine protected areas in the northwestern Mediterranean region: siting, usage, zonation and management. Aquat Conserv 11:155-188

Freitas R, Medina A, Correia S, Castro M (2007) Reproductive biology of spiny lobster Panulirus regius from the northwestern Cape Verde Islands. Afr J Mar Sci 29:201-208

> Galhardo AC, Serafim P, Castro M (2006) Aspects of the biology and fishery of the European spiny lobster (Palinurus elephas) from the southwest coast of Portugal. J Crustac Biol 26:601-609

Goñi R, Latrouite D (2005) Review of the biology, ecology and fisheries of Palinurus species of European waters: Palinurus elephas (Fabricius, 1787) and Palinurus mauritanicus (Gruvel, 1911). Cah Biol Mar 46:127-142

Goñi R, Reñones O, Quetglas A (2001) Dynamics of a protected Western Mediterranean population of the European spiny lobster Palinurus elephas (Fabricius, 1787) assessed by trap surveys. Mar Freshw Res 52:1577-1587

> Goñi R, Quetglas A, Reñones O (2003a) Size at maturity, fecundity and reproductive potential of a protected population of the spiny lobster Palinurus elephas (Fabricius, 1787) from the Western Mediterranean. Mar Biol 143:583-592 
Goñi R, Quetglas A, Reñones O (2003b) Differential catchability of male and female European spiny lobster Palinurus elephas (Fabricius, 1787) in traps and trammel nets. Fish Res 65:295-307

Goñi R, Quetglas A, Reñones O (2006) Spillover of spiny lobsters Palinurus elephas from a marine reserve to an adjoining fishery. Mar Ecol Prog Ser 308:207-219

Goñi R, Adlerstein S, Alvarez-Berastegui D, Forcada A and others (2008) Spillover from six western Mediterranean marine protected areas: evidence from artisanal fisheries. Mar Ecol Prog Ser 366:159-174

Goñi R, Hilborn R, Díaz D, Mallol S, Adlerstein S (2010) Net contribution of spillover from a marine reserve to fishery catches. Mar Ecol Prog Ser 400:233-243

Goñi R, Badalamenti F, Tupper MH (2011) Effects of marine protected areas on adjacent fisheries: evidence from empirical studies. In: Claudet J (ed) Marine protected areas: effects, networks and monitoring - a multidisciplinary approach. Cambridge University Press Ecology, Biodiversity and Conservation Series. Cambridge University Press, Cambridge

Green BS, Gardner C, Kennedy RB (2009) Generalised linear modelling of fecundity at length in southern rock lobsters, Jasus edwardsii. Mar Biol 156:1941-1947

Groeneveld JC (2005) Fecundity of spiny lobster Palinurus gilchristi (Decapoda: Palinuridae) off South Africa. Afr J Mar Sci 27:231-237

Halpern BS, Lester SE, Kellner JB (2010) Spillover from marine reserves and the replenishment of fished stocks. Environ Conserv 36:268-276

Hilborn R, Stokes K, Maguire JJ, Smith T and others (2004) When can marine reserves improve fisheries management? Ocean Coast Manag 47:197-205

Iacchei M, Robinson P, Miller KA (2005) Direct impacts of commercial and recreational fishing on spiny lobster, Panulirus interruptus, populations at Santa Catalina Island, California, United States. Mar Freshw Res 39:1201-1214

> Jack L, Wing SR (2010) Maintenance of old-growth size structure and fecundity of the red rock lobster Jasus edwardsii among marine protected areas in Fiordland, New Zealand. Mar Ecol Prog Ser 404:161-172

Jennings S (2001) Patterns and prediction of population recovery in marine reserves. Rev Fish Biol Fish 10: $209-231$

Jones GP, Almany GR, Russ GR, Sale PF, Steneck RS, van Oppen MJH, Willis BL (2009) Larval retention and connectivity among populations of corals and reef fishes:

Editorial responsibility: Tim McClanahan, Mombasa, Kenya history, advances and challenges. Coral Reefs 28:307-325

Kelly S, Scott D, MacDiarmid AB, Babcock R (2000) Spiny lobster, Jasus edwardsii, recovery in New Zealand marine reserves. Biol Conserv 92:359-369

Linnane A, Penny S, Hawthorne P, Hoare M (2009) Spatial differences in size of maturity and reproductive potential between inshore and offshore fisheries for southern rock lobster (Jasus edwardsii) in South Australia. Fish Res 96: $238-243$

Lyons WG, Barber DG, Foster SM, Kennedy FS, Milano GR (1981) The spiny lobster, Panulirus argus, in the Middle and Upper Florida Keys: population structure, seasonal dynamics, and reproduction. Florida Marine Research Publications No 38. Florida Department of Natural Resources, St. Petersburg, FL

MacDiarmid AB, Butler MJ IV (1999) Sperm economy and limitation in spiny lobsters. Behav Ecol Sociobiol 46:14-24

> Manríquez PH, Castilla JC (2001) Significance of marine protected areas in central Chile as seeding grounds for the gastropod Concholepas concholepas. Mar Ecol Prog Ser 215:201-211

Mayfield S, Branch G, Cockcroft AC (2005) Role and efficacy of marine protected areas for South African rock lobster, Jasus lalandii. Mar Freshw Res 56:913-924

Moffitt EA, Botsford LW, Kaplan DM, O'Farrell MR (2009) Marine reserve networks for species that move within a home range. Ecol Appl 19:1835-1847

Planes S, Jones GP, Thorrold SR (2009) Larval dispersal connects fish populations in a network of marine protected areas. Proc Natl Acad Sci USA 106:5693-5697

Rowe S (2001) Movements and harvesting mortality of American lobsters (Homarus americanus) tagged inside and outside no-take reserves in Bonavista Bay, Newfoundland. Can J Fish Aquat Sci 58:1336-1346

Russ GR (2002) Yet another review of marine reserves as reef fishery management tools. In: Sale P (ed) Coral reef fishes. Academic Press, San Diego, CA, p 421-443

Smith GG, Ritar AJ (2007) Sexual maturation in captive spiny lobsters, Jasus edwardsii, and the relationship of fecundity and larval quality with maternal size. Invertebr Reprod Dev 50:47-55

Tupper MH (2007) Spillover of commercially valuable reef fishes from marine protected areas in Guam, Micronesia. Fish Bull 105:527-537

- Walters C, Hilborn R, Parrish R (2007) An equilibrium model for predicting the efficacy of marine protected areas in coastal environments. Can J Fish Aquat Sci 64:1009-1018

Submitted: September 23, 2010; Accepted: April 27, 2011

Proofs received from author(s): June 30, 2011 